\title{
The Design Path of the Project Income Dividend Plan of the State-owned Technology Enterprise
}

\author{
Wang Han*1 Huo Aimin ${ }^{2}$ \\ ${ }^{1}$ State Grid Energy Research Institute Co.,Ltd., Beijing, China \\ ${ }^{2}$ State Grid Corporation of China, Beijing, China
}

\begin{abstract}
Project income dividend is one of the medium and long-term incentive methods commonly used by conventional technology enterprises, and it is also an important way for enterprises to stimulate technological innovation. In recent years, the number of state-owned technology-based enterprises that have distributed project income dividends has gradually increased, and they have all achieved good results. This article summarizes and sorts out the operating steps and common risks of project income dividends through analysis of the policy and practice of state-owned technology-based enterprise project income dividends. It provides an effective reference for the state-owned science and technology enterprises to carry out project income dividends.
\end{abstract}

\section{INTRODUCTION}

Project income dividend is a medium and long-term incentive method based on the project. The calculation of income is based on the project, and the distribution is based on the project. Simply put, the funds for project income dividends come from the income generated by the transformation of project results, and the main incentive objects for dividends are personnel closely related to the project. In other words, everything about the project's dividends revolves around the project itself. Therefore, the development of the project itself is the foundation that determines how the project's income and dividends will be carried out.[1] The operation of state-owned technology-based enterprise project income dividends is divided into 6 steps, "determine the project, determine the object, determine the amount, determine the distribution, determine the performance, determine the termination".

\section{Operational StePS for Dividend DIVIDENDS FROM PROJECTS OF STATE-OWNED TECHNOLOGY ENTERPRISES}

\section{A. Determine the Dividend Item}

First, we must select projects within the scope of scientific and technological achievements transformation projects. The "Interim Measures for State-owned Technological Enterprises Equity and Dividend Incentives" clearly stated that project income dividends are "based on the conversion of scientific and technological achievements." That is to say, projects that can pay dividends are specifically referred to as "scientific and technological achievements transformation projects", and not all projects can pay dividends. According to the "Law of the People's Republic of China on Promoting the Transformation of Scientific and Technological Achievements", "the transformation of scientific and technological achievements refers to the subsequent testing, development, application, and promotion of scientific and technological achievements of practical value produced by scientific research and technological development in order to improve the level of productivity until the formation of new products, new processes, new materials, and the development of new Industry and other activities".[2] It can be seen that the prerequisite for a project to become a scientific and technological achievement transformation project is that the project must be based on the investment of one or several scientific and technological achievements, and the work carried out in the project is to realize the transformation of scientific and technological achievements as the ultimate goal.

Second, it is necessary to select projects whose income can be independently accounted for. The "Interim Measures for State-owned Technology Enterprise Equity and Dividend Incentives" require that the implementation of project income dividends "should implement financial management in accordance with specific projects and conduct accounting in accordance with the unified national accounting system to reflect the status of specific project income dividends." Therefore, attention should be paid to selecting projects with clear boundaries and accurate allocation of benefits and costs, so as to correctly reflect the benefits of the project and avoid financial management and audit risks.[3]

Third, we must select projects that have been industrialized or are about to be industrialized. The "Interim Measures for State-owned Technology Enterprises Equity and Dividend Incentives" clearly stipulates that the execution of project income and dividends must be "after the completion and

\footnotetext{
* Corresponding author: wanghan@sgeri.sgcc.com.cn
} 
transformation of job scientific and technological achievements." The important prerequisite for the implementation of project income dividends is to "have dividends to be divided." Therefore, only after the project has entered or is about to enter the stage of industrialization, can it be possible to successfully complete the transformation of results and generate income and dividends for distribution.

Fourth, the number of projects to implement dividends should be determined according to the actual situation of the enterprise. The current relevant policies do not strictly limit the number of dividends that can be implemented at the same time. The company can comprehensively determine the number of projects that will implement profit sharing based on the actual number of projects, project progress, and employee status.

\section{B. Determine the Incentive Object}

At present, relevant policies do not specifically limit the scope of personnel who can enjoy project income dividends. Therefore, the incentive object only needs to meet the general requirement of "important technical personnel and management personnel who have signed labor contracts with the enterprise".

In the selection of specific incentive objects, attention should be paid to scientific research personnel who are closely related to the transformation of scientific and technological achievements, and some managers with a greater degree of correlation may be included in the scope of dividends. And in the selection of incentive objects, it is necessary to pay attention to the difference in the selection criteria of incentive objects from the job dividend.[4] The importance of relevant personnel in the project team and their contribution to the development of the project should be used as the main measurement criteria, and the influence of positions and levels in the selection of incentive objects should be minimized.

\section{Determine Incentive Amount}

The method for determining the amount of project income dividends is generally divided into the following two categories:

The first category is for companies to formulate relevant regulations in advance or agree with key technical personnel. After the achievement is completed and transformed, it shall be implemented in accordance with the method, amount and time limit specified by the enterprise or agreed in advance. Regarding the agreed award amount, enterprises can refer to the relevant requirements of the "Guidelines for the Implementation of Dividend Rewards for Central Technology Enterprises". "It can be combined with factors such as project source, project level, project scale, development stage and innovation contribution. Incentives can be appropriately increased for projects that have been established by the country and have made greater contributions to innovation. If the enterprise where the project is located is less than 3 years old or has not made a profit in the year of implementation, the overall quota shall be controlled in light of the project's profitability, or cashed in batches and times.[5]

The second category is that the company has neither stipulated nor agreed with important technical personnel. In this case, the company should determine the amount of incentives in accordance with the relevant provisions of the "Interim Measures on Equity and Dividend Incentives for State-owned Technological Enterprises" and the "Guidelines for the Implementation of Dividend Incentives for Central Technological Enterprises".

TABLE I. STANDARDS FOR DETERMINING THE DIVIDEND QUOTA OF STATE-OWNED TECHNOLOGICAL ENTERPRISES

\begin{tabular}{|c|c|}
\hline $\begin{array}{c}\text { Transformation methods of } \\
\text { scientific and technological } \\
\text { achievements }\end{array}$ & Project income dividend amount \\
\hline $\begin{array}{l}\text { Transfer and license the } \\
\text { technical achievements of the } \\
\text { job to others for } \\
\text { implementation }\end{array}$ & $\begin{array}{l}\text { The net income from the transfer of } \\
\text { the scientific and technological } \\
\text { achievements or the net income } \\
\text { from the license shall be used as } \\
\text { the extraction base, and the } \\
\text { incentive quota shall be drawn } \\
\text { according to the agreed or } \\
\text { prescribed ratio. In principle, a } \\
\text { one-time incentive is in place. } \\
\text { (Among them, the "Interim } \\
\text { Measures for State-owned } \\
\text { Technology Enterprises Equity and } \\
\text { Dividend Incentives" requires that } \\
\text { the withdrawal ratio is not less than } \\
50 \% \text { ) }\end{array}$ \\
\hline $\begin{array}{l}\text { Use the job's scientific and } \\
\text { technological achievements to } \\
\text { make investment }\end{array}$ & $\begin{array}{l}\text { If the investment income formed } \\
\text { by the shares (or capital } \\
\text { contribution ratio) of the scientific } \\
\text { and technological achievements is } \\
\text { used as the extraction base, the } \\
\text { incentive quota shall be drawn in } \\
\text { accordance with the agreement or } \\
\text { the prescribed ratio, and the } \\
\text { validity period shall not exceed } 5 \\
\text { years in principle. Where the } \\
\text { shares (or the proportion of capital } \\
\text { contribution) formed by the } \\
\text { investment of the technological } \\
\text { achievements of the job are used as } \\
\text { the extraction base, the } \\
\text { corresponding incentive amount, } \\
\text { proportion and other matters shall } \\
\text { be agreed in accordance with the } \\
\text { relevant provisions of equity } \\
\text { incentives. (Among them, the } \\
\text { "Interim Measures for State-owned } \\
\text { Technology Enterprise Equity and } \\
\text { Dividend Incentives" requires that } \\
\text { the withdrawal ratio is not less than } \\
50 \% \text { ) }\end{array}$ \\
\hline $\begin{array}{l}\text { Implement the scientific and } \\
\text { technological achievements of } \\
\text { the job by themselves or in } \\
\text { cooperation with others }\end{array}$ & $\begin{array}{l}\text { After the implementation of the } \\
\text { transformation is successfully put } \\
\text { into production for } 3 \text { to } 5 \\
\text { consecutive years, the incentive } \\
\text { amount will be drawn from the } \\
\text { operating profit of the } \\
\text { implementation of the scientific } \\
\text { and technological achievement in } \\
\text { accordance with the agreement or } \\
\text { the prescribed proportion. } \\
\text { (Among them, the "Interim } \\
\text { Measures for State-owned } \\
\text { Technology Enterprises Equity and } \\
\text { Dividend Incentives" requires that } \\
\text { the withdrawal ratio is not less than } \\
5 \% \text { ) }\end{array}$ \\
\hline
\end{tabular}




\section{Determine the Distribution Method}

In the allocation of incentive quota, the contribution of the incentive object in the project should generally be measured by the importance of the role of the incentive object in the project team and the work performance, and this shall be used as the basis for the quota allocation. In terms of measuring the importance of roles, it is generally possible to clarify the relative value and ranking of each position in the project by evaluating the value of the positions in the project. Make the dividend coefficient and the job value have a positive correlation, that is, the greater the job value, the higher the distribution coefficient should be. In terms of measuring work performance, generally the individual performance evaluation results of the incentive objects are used as the measurement standard.[6] Determine the dividend coefficient based on the annual performance evaluation results of the incentive objects, and use this as the basis for the distribution of project dividends.

In addition, in accordance with the requirements of the "Guidelines for the Implementation of Dividend Incentives for Central Technology Enterprises", in the distribution process, "the main completers and persons in charge of key scientific research tasks, major development projects, leading products or core technologies may appropriately increase the distribution ratio.’[7]

\section{E. Determine Performance Requirements}

The "Guidelines for the Implementation of Dividend Incentives for Central Technology Enterprises" clearly stipulate the performance evaluation requirements for the implementation of project income dividends.

In the selection of indicators, if you use job technology achievements as investment, self-implement or cooperate with others to implement project income and dividend incentives, you need to select at least one of project financial indicators, project innovation indicators, and project management indicators.[8] In the case of transfer of job-related scientific and technological achievements or license to others for implementation, if one-off incentives are not adopted, in principle, the assessment methods within the effective period of incentives should also be formulated in accordance with the above requirements.

TABLE II. STATE-OWNED TECHNOLOGY ENTERPRISE PROJECT INCOME DIVIDEND INCENTIVE PERFORMANCE EVALUATION INDEX

\begin{tabular}{|c|l|}
\hline Index category & \multicolumn{1}{c|}{ Indicator name } \\
\hline Project finance & $\begin{array}{l}\text { Project income growth rate, project } \\
\text { investment return rate, project net } \\
\text { profit growth rate, etc. }\end{array}$ \\
\hline Project innovation & $\begin{array}{l}\text { Number of project patents and } \\
\text { intellectual property rights, project } \\
\text { awards }\end{array}$ \\
\hline Project management & $\begin{array}{l}\text { The proportion of project R\&D } \\
\text { expenses in operating income, the } \\
\text { growth rate of the number } \\
\text { (amount) of new project contracts, } \\
\text { contract performance rate, etc. }\end{array}$ \\
\hline
\end{tabular}

At the assessment target level, the requirements of relevant policies on project income dividends are the same as job dividends. It is necessary to focus on the vertical comparison of its own historical performance levels, and encourage qualified enterprises to adopt the method of horizontal benchmarking with the performance of the same industry or benchmarking enterprises, and comprehensively determine the assessment target level.[9]

The first is to specify in the incentive plan the method of determining the evaluation target, and the selection of the method for the enterprise to target the target, and the principle of selecting the target enterprise shall be explained. The second is that the assessment target level setting should be comprehensively determined in consideration of factors such as enterprise operating conditions, industry cycles, and technological development plans. In principle, the relevant indicators shall not be lower than the actual performance level of the previous year or the average performance level of the company in the past three years, and the annual net profit growth index must be higher than the average growth level of the past three years The third is to introduce industry benchmarking, the relevant indicators should not be lower than the average performance of the same industry (or the 50th quantile value of the benchmarking company).[10]

Enterprises shall, in accordance with policy requirements, take the promotion of the transformation of scientific and technological achievements as the main purpose, and reasonably set indicators that can accurately reflect the economic benefits, social benefits, and innovation intensity of the transformation of scientific and technological achievements as the main basis for measuring project performance. This inspires the enthusiasm and creativity of scientific researchers in promoting the transformation of scientific and technological project results and promoting scientific research results to play new kinetic energy.

\section{F. Determine Change or Termination Conditions}

When the project team members leave the project team or cannot obtain the dividends of the project income due to other force majeure, they shall agree to adjust the original dividend agreement.[11] One is that it can be replaced by other personnel and become a new incentive object to enjoy the dividends of the project income. The second is that if there are no other substitutes, it can also be adjusted by adjusting the distribution ratio of the existing incentive objects, and the project team members will share the dividend share of the exiting personnel. 


\section{COMMON RISKS OF STATE-OWNED TECHNOLOGY ENTERPRISE PROJECT INCOME DIVIDENDS}

\section{A. Selection of Scientific and Technological Achievements Transformation Projects}

The requirements for the transformation of scientific and technological achievements are the points that companies often overlook when choosing to carry out profit sharing projects. As mentioned in the previous article, the projects that can be distributed are specifically referred to as "technological achievements transformation projects". The "Science and Technology Achievement Transformation Law" has a clear definition of the transformation of scientific and technological achievements. Refers to the follow-up experiments, development, application, and promotion of practically valuable scientific and technological achievements produced by scientific research and technological development in order to improve the level of productivity until the formation of new products, new processes, new materials, and the development of new industries.[12] The transformation of scientific and technological achievements refers specifically to projects carried out for the purpose of transformation, and are neither basic research projects nor "order projects" commissioned by third parties. A scientific and technological achievement transformation project should be an investment project to realize the transformation of achievements. The project must be based on the investment of one or several scientific and technological achievements as the prerequisite, and the work carried out in the project is to realize the transformation of scientific and technological achievements as the ultimate goal. Therefore, state-owned technology enterprises must be cautious in project selection when carrying out project income dividends.

\section{B. Project Income Accounting Method}

The project that implements the income distribution must be an independently accountable project, that is, the project income must be able to be effectively accounted and audited, and the project input, project income, and cost sharing can meet the audit requirements. This places very high requirements on the company's basic management. Due to financial constraints in most stateowned technology companies, the general technology projects are merged with the company's general ledger.[13] Unless there are special circumstances, it is rare for companies to take the initiative to conduct independent accounting for projects. In particular, part of the costs of personnel, equipment, and venues are shared by multiple projects, so it is very difficult to share. However, if the project is not independently accounted for, then the costs and benefits of the project cannot be clearly defined. When the project income is distributed, it will have a great impact on the calculation of the quota. In addition, there may be financial risks to the company due to the unclear basis for calculating the quota. Therefore, when choosing a project, you must choose a project with clear project boundaries and complete financial data to avoid financial and audit risks.

\section{Conclusion}

In recent years, the use of project income dividend incentives has become more widespread. Compared with job dividends, the incentive targets for project income dividends are more precise, and the incentive level verification is more scientific. Compared with equity incentives, the operation of project income dividends is relatively simple, and the incentive objects are mainly scientific and technical personnel who actually participate in scientific research. The above advantages of project income dividends are more in line with the main ideas of current state-owned technology enterprises to promote scientific and technological innovation. Therefore, more and more state-owned technology-based enterprises use project income dividends as the main way to carry out medium and long-term incentives.[14]

The operating steps of the project income dividend program include six steps: "determining the project, determining the target, the quota, the distribution, the performance, and the termination". Each step must not only follow the strict restrictions of the relevant system, but also integrate the actual development of the enterprise. The selected projects, the objects of incentives, the amount of dividends and the conditions for implementation must be made through scientific and democratic procedures. Only when the right project is selected and the right object is determined, the incentive can exert its due effect.

Enterprises need to pay attention to the selection of scientific and technological achievements transformation projects and the determination of project income accounting methods in the process of carrying out project income dividends. First, companies cannot choose scientific research projects commissioned by clients, and must choose self-research projects with initial cost input. The second is that enterprises should pay attention to the independent accounting of the project's own funds.

\section{Acknowledgment}

This project is supported by the State Grid Corporation of China Technology Project "Research on Talent Supply and Demand Analysis Model and Supply Strategy Research Adapting to Company Strategy" (SGSC0000KXJS2000095).

\section{REFERENCES}

1. Wu, X., Chen, Y., "Accelerate the Promotion of Medium and Long-term Incentives for State-owned Technology Enterprises," in Communication Enterprise Management, vol.10, Beijing , 2020, pp. 10-13.

2. Yuan, L., Chen, W., "Analysis and Suggestions on the Current Situation of Dividend Incentives for Scientific Research Projects of Central Enterprises," in Petroleum Science and Technology Forum, vol.37, Beijing, 2018, pp. 14-18..

3. Zhao, L., "Analysis on the Transformation Management of Scientific and Technological Achievements of State-owned 
Scientific and Technological Enterprises," in Science and Technology Innovation and Application, vol.16, Beijing , 2020, pp. 189-191.

4. Wang, X., Wei, L., "Research on the Innovation Incentive Mechanism of State-owned Technology Enterprises," in Journal of Jinan Vocational College, vol. 1, Jinan , 2019, pp. 94-97.

5. Zhang, J., "Tracking Evaluation of State-owned Technology Enterprises' Equity and Dividend Incentive Policies," in Science and Technology China, vol. 11, Beijing, 2020, pp. 44-49.

6. Zhang, P., "Transformation of scientific and technological achievements focuses on implementation," in Intellectual Property Research, vol. 26, Beijing, 2019, pp. 3-8.

7. Chen, Y., "Actively Promote the Establishment of Medium and Long-term Incentive Mechanisms for State-owned Enterprises," in China Electric Power Enterprise Management, vol.24, Beijing, 2020, pp. 10-12.

8. Zhang, Y., "Science and Technology Innovation Talents go First," in State Grid, vol. 7, Beijing, 2019, pp. 39-40.
9. $\mathrm{Si}, \mathrm{S}$., "Issues Related to Equity and Dividend Incentives of State-owned Technology Enterprises are Clear," in Commercial Accounting, vol. 23, Beijing, 2017, pp. 5.

10. Wang, B., "Research on Incentive Ways of Personnel in Modern State-owned Technology Enterprises," in Market Modernization, vol. 3, Beijing , 2018, pp. 102.

11. Yan, H., Li, Z., "Long-term Incentive Policies and Enlightenment of Aviation Industry," in Cooperative Economy and Technology, vol. 19, Beijing , 2020, pp. 123-125.

12. Qin, W., Xu, Q., "Thoughts on the Design of Medium and Longterm Incentive Schemes for State-owned Enterprises," in Market Modernization, vol. 2, Beijing, 2020, pp. 72-74.

13. Wan, S., "Analysis on the Construction of Enterprise Scientific and Technological Innovation," in Science \& Technology Economic Guide, vol. 28, Beijing, 2020, pp. 200+199.

14. Zhang, M., "Research on the Development Strategy of Technological Innovative Talents," in Modern Enterprise, vol. 11, Beijing, 2020, pp. 34-35. 